\title{
Chapter 8 \\ Social Origins of German Emigrants: \\ Maintaining Social Status Through \\ International Mobility?
}

Nils Witte, Reinhard Pollak, and Andreas Ette

\subsection{Introduction}

The question of intergenerational social mobility is a central concern in sociology. It describes the association between the socio-economic status of parents and the status their children attain as adults. Investigations of social mobility are inherently comparative, because no standard benchmark exists. The strength of the intergenerational correlation is always relative to specific reference groups or times. Most studies evaluate social mobility by the dynamic of this association over time and between generations, between (ethnic) groups within countries or between countries. The availability of more and better data over extended periods has boosted social mobility research in recent decades (Ganzeboom et al. 1991; Breen and Jonsson 2005). Several encompassing projects have studied intergenerational social mobility in the Western world (Breen 2004; Breen and Müller 2020a; Erikson and Goldthorpe 1992) but they continue to focus on the constellation within the nation state (Beck 2007; Weiß 2017). This chapter contributes to recent debates in social mobility research by analysing the impact of international spatial mobility on social mobility and the life chances of individuals. It compares German citizens who recently moved abroad ('emigrants') with the internationally non-mobile population in Germany ('non-migrants'). Since these emigrants move to various countries, this chapter also extends the geographical dimension of social mobility. Building on

\author{
N. Witte $(\triangle) \cdot$ A. Ette \\ Federal Institute for Population Research, Wiesbaden, Germany \\ e-mail: nils.witte@bib.bund.de; andreas.ette@bib.bund.de \\ R. Pollak \\ GESIS Leibniz Institute for the Social Sciences, Mannheim, Germany \\ University of Mannheim, Mannheim, Germany \\ e-mail: reinhard.pollak@gesis.org
}


findings about intragenerational wage mobility by Witte and Guedes Auditor (2021) in this volume, this chapter investigates class mobility between generations.

The prospect of upward social mobility is a central motive for spatial mobility and migration. Curiously, the nexus of spatial and social mobility attracted attention only relatively late. The potential existence of escalator regions within nation states sparked scholarly interest in the link of spatial and social mobility. The idea was that specific regional labour markets provided migrants with resources missing in their regions of origins and consequently increased their intra- and intergenerational mobility (Fielding 1992; Savage 1988). In the context of international migration, however, much research has investigated intragenerational mobility, whereas intergenerational social mobility has received less attention. Those who do analyse intergenerational mobility are often concerned with mobility between the first and second generation of migrants (Yaish 2002; Platt 2005). Accordingly, these studies have usually explored migrants' social mobility from a destination country perspective. Only more recently, studies in the context of intra-European mobility have analysed the spatial and social mobility of Europeans from various origins in several countries of destination (Recchi 2009; Favell and Recchi 2011). This chapter contributes to the literature on migration and social mobility by investigating the intergenerational social mobility from the perspective of the country of origin like the study by Zuccotti et al. (2017) does.

The chapter is organised around two sets of questions. The first one is concerned with the social origins of German emigrants and asks whether international mobility is the privilege of those from higher class origins as research in the European context suggests (Recchi 2009; Favell and Recchi 2011). How do existing social inequalities affect the opportunities to migrate internationally?

The second set of questions centres on the nexus between spatial and social mobility. Are relative rates of social mobility (often called social fluidity) about the same magnitude for emigrants and for non-migrants? Is emigration associated with downward mobility in terms of social classes as has been found for first generation Turkish emigrants in Europe (Zuccotti et al. 2017)? Or is migration more often associated with upward mobility as has been found at the sub-national level in industrialised countries like Germany and the USA (Reichelt and Abraham 2017; Yankow 2003; Waibel 2019)?

The chapter is structured as follows. We start by deriving tentative hypotheses from the literature on transnational human capital and on social mobility in Germany. Then we describe our data and analytical strategy before we present descriptive findings on absolute social mobility and log-linear models on relative rates of social mobility. We conclude with a short discussion of our findings and ideas for expanding our research. 


\subsection{Linking Spatial and Social Mobility}

International mobility offers migrants resources to maintain or even to improve their social status. Consequently, the positive selection of emigrants with respect to education and occupation is unsurprising (Borjas 1987, 1991; Dumont and Lemaître 2005; Parey et al. 2017; Chiquiar and Hanson 2005). As Ette and Witte (2021) find in this volume, Germany is no exception to the rule of positive selection by education. What is missing from these analyses is the social origin of migrants. A study on German students by Gerhards and Hans (2013) finds cultural and economic resources of parents to affect their offspring's likelihood to go abroad during school. Parents' cultural and economic resources matter, because early educational decisions and capital endowments create path dependencies that are difficult to reverse later in life. According to Carlson et al. (2017), German upper middle class families are more supportive of the generation of transnational cultural capital for their offspring compared with lower middle class families. From their perspective, the international experiences provide their children with resources to maintain or even improve their social status. The social difference in international spatial mobility is likely to continue during university. Indeed, university students whose parents hold tertiary degrees are more likely to go abroad than students whose parents hold lower degrees. This has been shown for several countries including Switzerland (Messer and Wolter 2007), Austria (Euler et al. 2013), and Germany (Lörz and Krawietz 2011). Path dependencies are likely to result in social selectivity of international mobility at later stages in life. Against this background, we would expect that German emigrants are more likely to originate from parents with academic educations than non-migrants are.

The selectivity of international mobility by social origin is relevant once we conceive of international mobility as an asset that defines opportunities and social outcomes (Bilecen and van Mol 2017). There is evidence that international mobility experiences improve labour market outcomes, at least for specific groups. Based on propensity score matching, one study finds positive labour market returns for graduates from occupationally unspecific fields in Germany (Waibel et al. 2018). Another study in the German context finds positive lagged effects of international mobility on the wage level 5 years after graduation (Kratz and Netz 2018). Positive wage effects are also found for students from other countries of origin (see Waibel et al. 2017 for an overview). Cross-national comparisons suggest positive labour market returns, which are larger in countries with poorer university quality and higher graduate unemployment (Jacob et al. 2019). Overall, there is evidence that international mobility is indeed conducive to various labour market outcomes including occupational status and wages.

A second perspective linking spatial and social mobility starts from the rigid German labour market (Breen and Luijkx 2004a, b). Early school-tracking is a central feature of the German education system that impairs social mobility (Büchler 2016; Bol and van de Werfhorst 2013). In addition, strong standardisation of occupational training and school-to-work linkages reduce occupational mobility during 
the later career compared with other countries (Allmendinger 1989; DiPrete et al. 2017; Witte 2020). Although social fluidity in Germany has increased in recent decades, it remains relatively low compared to the Scandinavian countries or Poland and Hungary (see Breen and Jonsson 2005 for an overview). Women in particular have benefitted from educational expansion and from increased demand for qualified personnel in the growing service sector (Müller and Pollak 2004, 2015; Hertel 2017; Pollak and Müller 2020). However, there are indications that opportunities for upward mobility have decreased again in the most recent cohorts (Mayer and Aisenbrey 2007; Klein 2011). Against the background of these findings, labour emigration from Germany is a potential pathway for upward social mobility. If the German labour market is rigid in international comparison, the obstruction of upward mobility is a potential motive for emigration. This would be in line with research findings that interregional mobility functions as a substitute for occupational mobility (Reichelt and Abraham 2017).

\subsection{Data and Analytical Strategy}

Our empirical analysis of the nexus between spatial and social mobility is based on the German Emigration and Remigration Panel Study (GERPS) (Ette et al. 2021). The first two waves provide detailed information about the social origin of internationally mobile German citizens as well as their own occupational careers. We draw equivalent information about the internationally non-mobile population from the German Socio-Economic Panel (SOEP) as the longest running longitudinal data infrastructure in Germany (Goebel et al. 2019). We restrict the analytical samples to persons in the age between 19 and 70 years and include only persons with nonmissing information about social class origin and destination. Furthermore, emigrants who arrived in their country of residence more than 2 years before the interview are excluded.

The analyses on social origins and intergenerational social mobility follow the class scheme provided by Erikson, Goldthorpe and Portocarero (EGP) as the de facto European standard in intergenerational mobility research. For the assignment of observations to EGP classes, we rely on Jann's (2019) Stata tool iscogen. GERPS and SOEP provide detailed information about the occupation of participants and their parents based on the International Standard Classification of Occupations (ISCO-08). Instead of information about the number of supervisees, however, we use information differentiating the parental occupational position (berufliche Stellung). We impute median values for each occupational position of the 2017 wave from the SOEP (v34). Since we collapse the EGP classes into their seven main classes, this inaccuracy does not affect our results. Parental class status stems from retrospective questions and refers to their occupation when respondents were 15 years old. When both parents were active in the labour market during respondents' youth, we let the maximum social class position of father and mother define the social class origin. 
Since class V "Manual workers with supervisory status" is undefined for nonmigrants in the SOEP, we collapse classes V and VI (skilled and semi-skilled manual) to facilitate comparisons between migrants and non-migrants. Furthermore, we subsume class IIIb (lower services) under unskilled labour as is common practice in social mobility research (Breen and Müller 2020b, p. 12). Diverging from the literature and due to small case numbers, we do not differentiate the self-employed with and without employees (IVab, IVc). Our final scheme includes the following six EGP classes: (I) Higher controllers, (II) Lower controllers, (IIIa) Routine nonmanuals, (IV) Self-employed with and without employees, (V/VI) Manual supervisors and skilled workers, and (VII/IIIb) Unskilled workers, lower sales services, and farm labour.

The analysis of the social origin of emigrants and non-migrants is based on absolute and relative rates of social mobility across different mobility tables. The starting point are mobility tables in which we arrange the classes of origin in the rows and the destination classes in the columns. Using column and row percentages, we can address the questions of which origin classes contribute to the composition of a given destination class (column percentages) and in which destination classes offspring from given origins end up (row percentages). These observed (absolute) mobility rates tell us something about the mobility experiences of emigrants and non-migrants. The composition of these two groups at stake differs markedly, so parts of the observed mobility rates are due to selection processes. In order to account for these compositional differences, we model relative rates of social mobility (social fluidity). We start again with the mobility tables and use log-linear models to simplify the task of comparing the odds of ending up in one social class rather than in another class (odds ratios) over all origin-destination pairs. We try to come up with a parsimonious log-linear model that reproduces the observed mobility tables as closely as possible. To assess whether our models generate fitted values of the observed values in our mobility tables we use goodness-of-fit statistics (Breen 2020). The goodness-of-fit statistics include the deviance $\left(\mathrm{G}^{2}\right.$ or $\left.\mathrm{L}^{2}\right)$ relative to the model parameters and the Bayesian Information Criterion (BIC). For the comparison of social fluidity, we use a model of uniform difference (unidiff) between mobility tables of emigrants and non-migrants (Erikson and Goldthorpe 1992; Xie 1992). Its basic idea is that the associations (measured in logged odds ratios) between origin and destination classes form a certain empirical pattern, for example a strong association of upper service class vs. unskilled labour positions, but a weak association between skilled labour vs. unskilled labour positions. Such an empirical pattern is assumed to be the same between the two tables that are compared, but the strength of the given associations is allowed to differ uniformly by a single factor between the two tables. The goodness-of-fit measures inform us whether the empirical fit improves once we allow the strength of the association patterns to differ between the two groups.

A final step of the analysis takes account of the positive selection of emigrants along various characteristics (cf. Ette and Witte 2021). For a better judgment of mobility processes, we account for this selectivity by forming two comparable groups. We adjust the non-migrant sample to the distribution of relevant 
characteristics in our analytical GERPS sample through entropy balancing (Hainmueller 2012) using Hainmueller and Xu's (2013) Stata implementation ebalance. The method has been designed as a more efficient alternative to matching procedures. We balance the non-migrant sample according to characteristics of the emigrant sample in order to control for this selectivity. The covariate moments for our reweighting procedure include age in years and its squared and cubed terms, six dummies for social origin classes, and gender.

\subsection{Social Origins of German Emigrants}

Comparing the parental education of emigrants and non-migrants already provides first evidence that emigrants originate from higher social backgrounds compared with non-migrants (see Table 8.1). Parents' educational degrees are on average much higher among emigrants compared with non-migrants. While fathers and mothers without degrees are rare in both groups and intermediate degrees similarly common in both groups, lower secondary degrees are more common among nonmigrants' parents. About 54\% of non-migrants mothers and fathers, but just $18 \%$ of emigrants' parents, hold lower secondary degrees. For higher secondary degrees it is the opposite case. Just $11 \%$ of non-migrants' mothers and $17 \%$ of their fathers hold higher secondary degrees. These shares are much higher among emigrants. Almost half of emigrants' mothers and 55\% of their fathers hold higher secondary degrees. The social background gap between emigrants and non-migrants is even more pronounced once we consider academic degrees. While $16 \%$ of non-migrants

Table 8.1 Parental education of emigrants and nonmigrants (in \%)

\begin{tabular}{l|l|l}
\hline & Non-migrants & Emigrants \\
\hline Mother schooling & & \\
\hline No degree & & 1 \\
\hline Lower secondary & 54 & 18 \\
\hline Intermediate & 27 & 30 \\
\hline Higher secondary & 11 & 47 \\
\hline Father schooling & & \\
\hline No degree & & 1 \\
\hline Lower secondary & 2 & 18 \\
\hline Intermediate & 54 & 20 \\
\hline Higher secondary & 19 & 55 \\
\hline Academic degree parents & 17 & \\
\hline None & 84 & 43 \\
\hline One & 11 & 28 \\
\hline Both & 5 & 30 \\
\hline
\end{tabular}

Sources: SOEP2017 (weighted), GERPSw1

a Sums diverging from $100 \%$ are caused by missing values, unspecified categories, or rounding 
have at least one parent with an academic degree, this is the case for $58 \%$ of emigrants. Thus, emigrants are 3.6 times more likely to have academic parents than non-migrants are. Overall, these descriptive findings suggest that emigrants are more likely to come from higher social backgrounds compared with non-migrants.

This finding based on parental education is even more pronounced once social class origins are taken into account. Table 8.2 shows the proportion of individuals in destination classes coming from each origin class for non-migrants (Panel A) and emigrants (Panel B). Eighty-six per cent of emigrants originate from the two highest service classes. About equal proportions of emigrants come from each of the highest social classes. Among non-migrants, about one third originates from the top classes while just as many originate from the low manual classes. While one in ten nonmigrants originates from the Unskilled Service class, almost none of the emigrants originate from this class. Only the proportion originating from class IV of the Selfemployed is similar in both groups. When it comes to securing class positions, the heritability is particularly strong in the upper service classes. Almost one in three non-migrants and one in two emigrants secures their higher service class positions. Class inheritability among non-migrants, however, is strongest for the lowest manual classes, where $37 \%$ inherited that class from their parents. Overall, these statistics indicate that German emigrants are indeed strongly positively selected by their social class origin.

Finally, Table 8.3 shows how individuals from each class origin distribute over destination classes. Panel A shows outflows of non-migrants and Panel B shows outflows of emigrants. More than half of non-migrants are destined for the three

Table 8.2 Intergenerational social mobility of (A) non-migrants and (B) emigrants (inflows, column per cent)

\begin{tabular}{|c|c|c|c|c|c|c|c|}
\hline \multirow{2}{*}{ Origin class } & \multicolumn{7}{|c|}{ Destination class } \\
\hline & I & II & IIIa & IV & V/VI & VII/ IIIb & Total \\
\hline \multicolumn{8}{|c|}{ (A) Non-migrants } \\
\hline I & 30 & 20 & 14 & 10 & 9 & 9 & 16 \\
\hline II & 29 & 26 & 20 & 20 & 13 & 14 & 21 \\
\hline IIIa & 9 & 11 & 12 & 9 & 9 & 10 & 10 \\
\hline IV & 5 & 4 & 5 & 10 & 6 & 5 & 5 \\
\hline $\mathrm{V} / \mathrm{VI}$ & 12 & 17 & 18 & 20 & 26 & 25 & 20 \\
\hline VII/IIIb & 16 & 22 & 31 & 31 & 36 & 37 & 28 \\
\hline Total & 100 & 100 & 100 & 100 & 100 & 100 & 100 \\
\hline \multicolumn{8}{|c|}{ (B) Emigrants } \\
\hline I & 46 & 40 & 22 & 34 & 15 & 24 & 41 \\
\hline II & 41 & 48 & 57 & 45 & 58 & 44 & 45 \\
\hline IIIa & - & - & 1 & 3 & - & - & - \\
\hline IV & 6 & 4 & 8 & 7 & 3 & 12 & 6 \\
\hline V/VI & 3 & 5 & 7 & 3 & 21 & 9 & 5 \\
\hline VII/IIIb & 3 & 3 & 5 & 7 & 3 & 12 & 3 \\
\hline Total & 100 & 100 & 100 & 100 & 100 & 100 & 100 \\
\hline
\end{tabular}

$N_{\text {non-migrants }}=13,652, N_{\text {emigrants }}=1523$. Sources: SOEP2017 (weighted), GERPSw1 
Table 8.3 Intergenerational social mobility of (A) non-migrants and (B) emigrants (outflows, row per cent)

\begin{tabular}{|c|c|c|c|c|c|c|c|}
\hline \multirow[b]{2}{*}{ Origin class } & \multicolumn{7}{|c|}{ Destination class } \\
\hline & I & II & IIIa & IV & V/VI & $\mathrm{VII} / \mathrm{IIIb}$ & Total \\
\hline \multicolumn{8}{|c|}{ (A) Non-migrants } \\
\hline I & 27 & 36 & 12 & 3 & 7 & 15 & 100 \\
\hline II & 20 & 35 & 14 & 4 & 8 & 18 & 100 \\
\hline IIIa & 12 & 30 & 16 & 4 & 12 & 26 & 100 \\
\hline IV & 14 & 20 & 15 & 8 & 16 & 27 & 100 \\
\hline V/VI & 9 & 24 & 13 & 4 & 17 & 34 & 100 \\
\hline $\mathrm{VII} / \mathrm{IIIb}$ & 8 & 21 & 15 & 5 & 17 & 34 & 100 \\
\hline Total & 15 & 28 & 14 & 4 & 13 & 27 & 100 \\
\hline
\end{tabular}

(B) Emigrants

\begin{tabular}{l|l|l|r|r|r|l|l}
\hline I & $\mathbf{5 6}$ & 38 & 3 & 2 & 1 & 1 & 100 \\
\hline II & 45 & $\mathbf{4 2}$ & 6 & 2 & 3 & 2 & 100 \\
\hline IIIa & 43 & 29 & $\mathbf{1 4}$ & 14 & 0 & 0 & 100 \\
\hline IV & 55 & 30 & 7 & $\mathbf{2}$ & 1 & 5 & 100 \\
\hline V/VI & 36 & 42 & 7 & 1 & $\mathbf{1 0}$ & 4 & 100 \\
\hline VII/IIIb & 42 & 33 & 9 & 4 & 2 & $\mathbf{9}$ & 100 \\
\hline Total & 50 & 39 & 5 & 2 & 2 & 2 & 100
\end{tabular}

$N_{\text {non-migrants }}=13,652, N_{\text {emigrants }}=1523$. Sources: SOEP2017 (weighted), GERPSw1

higher classes (I, II, IIIa), while just $40 \%$ end up in the lower classes. Emigrants are even more concentrated at the top of the social class hierarchy. Nine in ten emigrants are in the top service classes. Just $4 \%$ of emigrants belong to the manual classes. Along these lines, one third of non-migrants' lower manual class parents bestow their position to their offspring while that is true for just $9 \%$ of emigrants. Conversely, more than half of emigrants' parents bestow their higher service class membership to their offspring, while just $27 \%$ of non-migrants do. Overall, these descriptive findings about class destinations indicate that German emigrants are also positively selected by their present social class membership.

\subsection{International Migration and Social Fluidity}

Next to the social origins of the internationally mobile population, we are interested in the association of spatial mobility and social mobility. Descriptive findings indicate that social mobility is higher among non-migrants compared with emigrants (see Table 8.4). One fourth of non-migrants remain in the same social class as their parents, while the same is true of $43 \%$ of emigrants. One reason is the higher proportion of top class members among emigrants compared with non-migrants that we documented above. Those originating from the highest class cannot be upwardly mobile per definition. However, emigrants originating from the top service classes (I, II) are more likely to secure their class position than non-migrants whose parents 
Table 8.4 Overall intergenerational mobility of emigrants and non-migrants based on unbalanced and balanced samples (column per cent)

\begin{tabular}{l|l|l|l}
\hline & Emigrants & Non-migrants \\
\hline & & Unbalanced & Balanced $^{\mathrm{a}}$ \\
\hline Upward mobility & 33 & 39 & 17 \\
\hline Non-mobility & 43 & 27 & 34 \\
\hline Downward mobility & 25 & 34 & 50 \\
\hline Thereof ... & & & \\
\hline Short-distance upward mobility & 21 & 14 & 12 \\
\hline Long-distance upward mobility & 12 & 26 & 5 \\
\hline Short-distance downward mobility & 19 & 16 & 23 \\
\hline Long-distance downward mobility & 6 & 17 & 27 \\
\hline Total & 100 & 100 & 100 \\
\hline
\end{tabular}

$N_{\text {non-migrants }}=13,652, N_{\text {emigrants }}=1523$. Inaccuracies owed to rounding. Sources: SOEP2017 (weighted), GERPSw1

${ }^{a}$ Adjusted to emigrant sample through entropy balancing

belong to these social classes. Among non-migrants, $27 \%$ with parents from class I and $35 \%$ with parents from class II inherit their class position (see Table 8.3). Among emigrants, the respective figures are distinctly higher with $56 \%$ and $42 \%$ securing their class position respectively.

Table 8.4 further differentiates long and short-distance social mobility. Short distances are defined as mobility to neighbouring classes, while long distances are more than one class apart. Long-distance social mobility is remarkably low among emigrants from all class origins. The proportion of long-distance downward mobility is $6 \%$ among emigrants compared to $17 \%$ among non-migrants. Similarly, longdistance upward mobility is half as frequent among emigrants (12\%) as among non-migrants $(26 \%)$.

In both groups, more individuals are upwardly mobile than downwardly mobile. $39 \%$ of non-migrants and $33 \%$ of emigrants are upwardly mobile. One relevant difference between non-migrants and emigrants in this respect is that emigrants reach the two highest service classes more often than non-migrants do. However, emigrants originate from these classes more often. Non-migrants are also more often downwardly mobile (34\%) than emigrants are (25\%). Overall, there is more social mobility among non-migrants than among emigrants.

Social mobility among non-migrants changes radically once we adjust the sample of non-migrants to relevant distributions of emigrants. Through entropy balancing according to social class origin, age, and gender we enable comparisons of samples with similar distributions of key characteristics in both samples. On average, non-migrants with similar characteristics as emigrants are less class mobile than non-migrants in general. About one third secures the class position of their parents, given the selective favourable class background of emigrants. Interestingly, non-mobility rates are still nine percentage points lower compared to $43 \%$ among emigrants. Emigration seems to suppress (downward) social mobility, it keeps emigrants in the mostly favourable class of origin. In sharp contrast, non-migrants with 
comparable characteristics as emigrants face much higher rates of downward mobility; the rate increases to $50 \%$. Both, short-distance and long-distance downward mobility, increase for this analytical group. Overall, comparable non-migrants are twice as often downwardly mobile as emigrants, and the differences are particularly pronounced with respect to long-distance downward mobility.

At the same time, upward mobility rates are much lower for the balanced sample of non-migrants. Even though emigrants are already a positively selected group, they benefit with respect to upward mobility. They are twice as often upwardly mobile (33\%) as non-migrants in the balanced sample. The upshot is that the positive association of emigration and upward social mobility and the negative association with downward mobility become stronger once we take non-migrants with similar characteristics as emigrants as our reference.

Table 8.5, Panel A, shows the results of log-linear models of the two-way association between origins and destinations (OD) for the two groups of emigrants and non-migrants. We test Erikson and Goldthorpe's (1992) unidiff model against the common social fluidity model based on Vermunt's (1997) software lem to fit the models. The unidiff model does not describe the data better judged by the higher BIC and it is not significantly better than the baseline model according to a Chisquare test on the difference in the $\mathrm{G}^{2}$. The unidiff model reduces the deviance by just 3.1\% ((27.5-28.4)/28.4) compared with the common social fluidity model. The results indicate that social mobility among emigrants is not different from social mobility among non-migrants. Furthermore, we fit a more flexible version of the unidiff model to account for the concentration of observations in the higher service class origins and destinations. For variation of the unidiff model, we estimated two separate unidiff parameters for mobility between the service classes and for the rest of the table. However, neither are these changes a statistically significant improvement of the baseline model.

Table 8.5, Panel B, shows the results of log-linear models applying entropy balancing to adjust the non-migrant distribution of key characteristics to the distribution of emigrants. However, the results are rather similar to the ones obtained without adjusted samples. The unidiff model does not fit the data better than the

Table 8.5 Goodness of fit of models of common social fluidity and unidiff of emigrants and nonmigrants for (A) unbalanced and (B) balanced samples

\begin{tabular}{l|l|l|l|l|l|l|l|l}
\hline & & $\mathrm{G}^{2}$ & df & p & Diss. index & Delta G $^{2}$ & BIC & p vs. 1 \\
\hline \multicolumn{2}{l|}{ (A) Unbalanced sample } & & & & & & & \\
\hline ODM & Com. social fluidity & 28.4 & 25 & 0.2894 & 0.0059 & & -212 & \\
\hline & Unidiff & 27.5 & 24 & 0.2795 & 0.0058 & 0.9 & -203 & 0.3428 \\
\hline & Unidiff-2 & 27.2 & 23 & 0.2455 & 0.0058 & 1.2 & -194 & 0.5488 \\
\hline (B) Balanced sample & & & & & & & \\
\hline ODM & Com. social fluidity & 31.4 & 25 & 0.1750 & 0.0072 & & -209 & \\
\hline & Unidiff & 28.3 & 24 & 0.4261 & 0.0058 & 3.1 & -203 & 0.0783 \\
\hline & Unidiff-2 & 28.2 & 23 & 0.2091 & 0.0056 & 3.2 & -193 & 0.2019 \\
\hline
\end{tabular}

$N_{\text {non-migrants }}=13,652, N_{\text {emigrants }}=1523 . \mathrm{O}=$ Origin; $\mathrm{D}=$ Destination; $\mathrm{M}=$ Migration status. Sources: SOEP2017, GERPSw1 
constant fluidity model. This finding also holds for the variation of the unidiff model where we estimate two separate unidiff parameters for mobility between the service classes and for the rest of the table. Results presented in panel B thus corroborate the finding that social mobility is not systematically different between non-migrants and emigrants.

The results of the unidiff model exercise are evident by all conventions. Neither the model fit with respect to $\mathrm{G}^{2}$ nor the BIC measure suggest a robust difference in social fluidity between emigrants and non-migrants. The results may surprise at first glance, since we did see favourable patterns of emigration for more upward and less downward mobility. Yet, the number of observations in our analysis might be (yet) too low and the (conventional) unidiff model too coarse to detect the differences between the groups. Per se, the mobility patterns and the strength of the association between social origin and destination class seem to be similar. The main finding is that offspring from favourable classes are able to maintain their favourable class positions. This is true for the (non-migrant) population per se, and this is in particular true for the group of emigrants.

\subsection{Discussion and Conclusion}

This chapter aimed to describe the social origins of German emigrants and to explore differences in social mobility between these emigrants and German nonmigrants. Our results indicate that German emigrants are positively selected both with respect to their social origin class and with respect to their present social class. In other words, German emigrants are more likely to come from privileged educational backgrounds. On average, emigrants' parents hold higher school degrees and are more often in possession of tertiary degrees compared with non-migrants' parents. This is in line with earlier findings that studying abroad is more likely when parents hold academic degrees (Lörz and Krawietz 2011; Messer and Wolter 2007; Euler et al. 2013). Furthermore, emigrants are more likely to originate from higher social classes than non-migrants and they are more likely to presently belong to these classes. This is an indication that international mobility throughout the career mirrors the class dependency of studying abroad during school (Carlson et al. 2017).

We find no difference in social fluidity between emigrants and non-migrants. Our finding is robust to sensitivity tests that account for the concentration of emigrants in the upper service classes. Furthermore, it is robust to balancing the non-migrant sample according to the distribution of key characteristics among emigrants. This finding is in line with research in the context of EU mobility showing that the intergenerational mobility of intra-European movers does not differ significantly from that of stayers (Recchi 2009; Favell and Recchi 2011). However, it contradicts our tentative hypothesis that emigration facilitates sidestepping the rigidity of the German labour market. While wage mobility could be an incentive for German emigration (Witte and Guedes Auditor 2021), vertical social mobility apparently is not. Furthermore, Favell and Recchi's (2011) ESS-based analyses show that EU 
migrants are more likely to end up in higher than lower class destinations and that this positive association is particularly strong among German emigrants.

Overall, the findings in this chapter indicate that international mobility and migration from Germany is the prerogative of the higher classes providing them with additional resources to maintain their social status. That underlines the importance international migration has for intergenerational social mobility in economically highly developed countries. Future research should expand on our findings in at least two directions. First, we did not address the crucial influence of education for social mobility (e.g. Breen and Müller 2020b). The inclusion of education and other mediating forces like cohort effects are next on the agenda. Second, separate analyses for men and women could reveal different mechanisms of social mobility by gender. Such additional analyses should also account for eventual periods of inactivity that "tied movers" (Erlinghagen 2021) are likely to experience immediately after migration. If women are disproportionally affected by this phenomenon, the class scheme must account for inactive persons to avoid gender bias in the mobility results (see Beller 2009). We need more research to establish the consequences of spatial mobility in early life for both spatial and social mobility through the life course.

\section{References}

Allmendinger, J. (1989). Educational systems and labour market outcomes. European Sociological Review, 5(3), 231-250.

Beck, U. (2007). Beyond class and nation: Reframing social inequalities in a globalizing world. The British Journal of Sociology, 58(4), 679-705.

Beller, E. (2009). Bringing intergenerational social mobility research into the twenty-first century: Why mothers matter. American Sociological Review, 74, 507-528.

Bilecen, B., \& van Mol, C. (2017). Introduction: International academic mobility and inequalities. Journal of Ethnic and Migration Studies, 43(8), 1241-1255.

Bol, T., \& van de Werfhorst, H. G. (2013). Educational systems and the trade-off between labor market allocation and equality of educational opportunity. Comparative Education Review, 57(2), 285-308.

Borjas, G. J. (1987). Self-selection and the earnings of immigrants. The American Economic Review, 77(4), 531-553.

Borjas, G. J. (1991). Immigration and self-selection. In J. M. Abowd \& R. B. Freeman (Eds.), Immigration, trade and the labor market (pp. 29-76). Chicago: University of Chicago Press.

Breen, R. (2004). Social mobility in Europe. New York: Oxford University Press.

Breen, R. (2020). Methodological preliminaries. In R. Breen \& W. Müller (Eds.), Education and intergenerational social mobility in Europe and the United States (pp. 20-28). Stanford: Stanford University Press.

Breen, R., \& Jonsson, J. O. (2005). Inequality of opportunity in comparative perspective: Recent research on educational attainment and social mobility. Annual Review of Sociology, 31(1), 223-243.

Breen, R., \& Luijkx, R. (2004a). Conclusions. In R. Breen (Ed.), Social mobility in Europe (pp. 383-410). New York: Oxford University Press.

Breen, R., \& Luijkx, R. (2004b). Social mobility in Europe between 1970 and 2000. In R. Breen (Ed.), Social mobility in Europe (pp. 37-76). New York: Oxford University Press. 
Breen, R., \& Müller, W. (Eds.). (2020a). Education and intergenerational social mobility in Europe and the United States. Stanford: Stanford University Press.

Breen, R., \& Müller, W. (2020b). Introduction: Social mobility and education in the 20th century. In R. Breen \& W. Müller (Eds.), Education and intergenerational social mobility in Europe and the United States (pp. 1-19). Stanford: Stanford University Press.

Büchler, T. (2016). Schulstruktur und Bildungsungleichheit: Die Bedeutung von bundeslandspezifischen Unterschieden beim Übergang in die Sekundarstufe I für den Bildungserfolg. Kölner Zeitschrift für Soziologie und Sozialpsychologie, 68(1), 53-87.

Carlson, S., Gerhards, J., \& Hans, S. (2017). Educating children in times of globalisation: Classspecific child-rearing practices and the acquisition of transnational cultural capital. Sociology, 51(4), 749-765.

Chiquiar, D., \& Hanson, G. H. (2005). International migration, self-selection, and the distribution of wages: Evidence from Mexico and the United States. Journal of Political Economy, 113(2), 239-281.

DiPrete, T. A., Bol, T., Eller, C. C., \& van de Werfhorst, H. G. (2017). School-to-work linkages in the United States, Germany, and France. American Journal of Sociology, 122(6), 1869-1938.

Dumont, J.-C., \& Lemaître, G. (2005). Counting immigrants and expatriates in OECD countries. OECD Social, Employment and Migration Working Papers 25. Paris.

Erikson, R., \& Goldthorpe, J. H. (1992). The constant flux. In A study of class mobility in industrial societies. Oxford: Clarendon Press.

Erlinghagen, M. (2021). Migration motives, timing, and outcomes of internationally mobile couples. In M. Erlinghagen, A. Ette, N. F. Schneider, \& N. Witte (Eds.), The global lives of german migrants. Consequences of international migration across the life course. Cham: Springer.

Ette, A., Décieux, J. P., Erlinghagen, M., Guedes Auditor, J., Sander, N., Schneider, N. F., \& Witte, N. (2021). Surveying across borders: The experiences of the German emigration and remigration panel study. In M. Erlinghagen, A. Ette, N. F. Schneider, \& N. Witte (Eds.), The global lives of German migrants. Consequences of international migration across the life course. Cham: Springer.

Ette, A., \& Witte, N. (2021). Brain drain or brain circulation? Economic and non-economic factors driving the international migration of german citizens. In M. Erlinghagen, A. Ette, N. F. Schneider, \& N. Witte (Eds.), The global lives of german migrants. Consequences of international migration across the life course. Cham: Springer.

Euler, H. P., Rami, U., Glaser, E., Reber, G., \& Bacher, J. (2013). Lohnt sich ein Auslandsaufenthalt während des Studiums?: Ergebnisse der Evaluierung eines Förderprogrammes. DBW Die Betriebswirtschaft, 73(5), 425-446.

Favell, A., \& Recchi, E. (2011). Social mobility and spatial mobility: Chapter 3. In A. Favell (Ed.), Sociology of the European Union (pp. 50-75). Basingstoke: Palgrave Macmillan.

Fielding, A. J. (1992). Migration and social mobility: South East England as an escalator region. Regional Studies, 26(1), 1-15.

Ganzeboom, H. B. G., Treiman, D. J., \& Ultee, W. C. (1991). Comparative intergenerational stratification research: Three generations and beyond. Annual Review of Sociology, 17(1), 277-302.

Gerhards, J., \& Hans, S. (2013). Transnational human capital, education, and social inequality. Analyses of international student exchange. Zeitschrift für Soziologie, 42(2), 99-117.

Goebel, J., Grabka, M. M., Liebig, S., Kroh, M., Richter, D., Schröder, C., \& Schupp, J. (2019). The German socio-economic panel (SOEP). Jahrbücher für Nationalökonomie und Statistik, 239(2), 345-360.

Hainmueller, J. (2012). Entropy balancing for causal effects: A multivariate reweighting method to produce balanced samples in observational studies. Political Analysis, 20, 25-46.

Hainmueller, J., \& Xu, Y. (2013). ebalance: A stata package for entropy balancing. Journal of Statistical Software, 54, 7.

Hertel, F. R. (2017). Social mobility in the 20th century: Class mobility an occupational change in the United States and Germany. Wiesbaden: Springer Fachmedien. 
Jacob, M., Kühhirt, M., \& Rodrigues, M. (2019). Labour market returns to graduates' international experience: Exploring cross-country variation in Europe. European Sociological Review, $35(4), 491-505$.

Jann, B. (2019). ISCOGEN: Stata module to translate ISCO codes. Boston College Department of Economics.

Klein, M. (2011). Trends in the association between educational attainment and class destinations in West Germany: Looking inside the service class. Research in Social Stratification and Mobility, 29(4), 427-444.

Kratz, F., \& Netz, N. (2018). Which mechanisms explain monetary returns to international student mobility? Studies in Higher Education, 43(2), 375-400.

Lörz, M., \& Krawietz, M. (2011). Internationale Mobiltät und soziale Selektivität: Ausmaß, Mechanismen und Entwicklung herkunftsspezifischer Unterschiede zwischen 1990 und 2005. Kölner Zeitschrift für Soziologie und Sozialpsychologie, 63(2), 185-205.

Mayer, K. U., \& Aisenbrey, S. (2007). Variations on a theme: Trends in social mobility in (West) Germany for cohorts born between 1919 and 1971. In S. Scherer, R. Pollak, G. Otte, \& M. Gangl (Eds.), From origin to destination. Trends and mechanisms in social stratification research (pp. 125-154). Frankfurt am Main/New York: Campus.

Messer, D., \& Wolter, S. C. (2007). Are student exchange programs worth it? Higher Education, 54(5), 647-663.

Müller, W., \& Pollak, R. (2004). Social mobility in West Germany: The long arms of history discovered? In R. Breen (Ed.), Social mobility in Europe (pp. 77-113). New York: Oxford University Press.

Müller, W., \& Pollak, R. (2015). Bildung und soziale Mobilität in Deutschland. AStA Wirtschaftsund Sozialwissenschaftliches Archiv, 9, 5-26.

Parey, M., Ruhose, J., Waldinger, F., \& Netz, N. (2017). The selection of high-skilled emigrants. The Review of Economics and Statistics, 99(5), 776-792.

Platt, L. (2005). The intergenerational social mobility of minority ethnic groups. Sociology, 39(3), 445-461.

Pollak, R., \& Müller, W. (2020). Education as an equalizing force: How declining educational inequality and educational expansion have contributed to more social fluidity in Germany. In R. Breen \& W. Müller (Eds.), Education and intergenerational social mobility in Europe and the United States (pp. 122-149). Stanford: Stanford University Press.

Recchi, E. (2009). The social mobility of mobile Europeans. In E. Recchi \& A. Favell (Eds.), Pioneers of European integration: Citizenship and mobility in the EU (pp. 72-97). Edward Elgar Publishing, Incorporated.

Reichelt, M., \& Abraham, M. (2017). Occupational and regional mobility as substitutes: A new approach to understanding job changes and wage inequality. Social Forces, 95(4), 1399-1426.

Savage, M. (1988). The missing link? The relationship between spatial mobility and social mobility. The British Journal of Sociology, 39(4), 554-577.

Vermunt, J. K. (1997). LEM 1.0: A gerneral program for the analysis of categorical data. Tilburg: Tilburg University.

Waibel, S. (2019). Does spatial mobility in young adulthood matter? Indirect and direct effects of spatial mobility during education on occupational status. BiB Working Paper. Wiesbaden.

Waibel, S., Petzold, K., \& Rüger, H. (2018). Occupational status benefits of studying abroad and the role of occupational specificity-A propensity score matching approach. Social Science Research, 74, 45-61.

Waibel, S., Rüger, H., Ette, A., \& Sauer, L. (2017). Career consequences of transnational educational mobility: A systematic literature review. Educational Research Review, 20, 81-98.

Weiß, A. (2017). Soziologie Globaler Ungleichheiten. Berlin: Suhrkamp.

Witte, N. (2020). Have changes in gender segregation and occupational closure contributed to increasing wage inequality in Germany, 1992-2012? European Sociological Review, 36(2), 236-249. 
Witte, N., \& Guedes Auditor, J. (2021). Affluent lives beyond the border? Individual wage change through migration. In M. Erlinghagen, A. Ette, N. F. Schneider, \& N. Witte (Eds.), The global lives of German migrants. Consequences of international migration across the life course. Cham: Springer.

Xie, Y. (1992). The log-multiplicative layer effect model for comparing mobility tables. American Sociological Review, 57(3), 380-395.

Yaish, M. (2002). The consequences of immigration for social mobility: The experience of Israel. European Sociological Review, 18(4), 449-471.

Yankow, J. J. (2003). Migration, job change, and wage growth: A new perspective on the pecuniary return to geographic mobility. Journal of Regional Science, 43(3), 483-516.

Zuccotti, C. V., Ganzeboom, H. B. G., \& Guveli, A. (2017). Has migration been beneficial for migrants and their children?: Comparing social mobility of Turks in Western Europe, Turks in Turkey, and Western European Natives. International Migration Review, 51(1), 97-126.

Open Access This chapter is licensed under the terms of the Creative Commons Attribution 4.0 International License (http://creativecommons.org/licenses/by/4.0/), which permits use, sharing, adaptation, distribution and reproduction in any medium or format, as long as you give appropriate credit to the original author(s) and the source, provide a link to the Creative Commons license and indicate if changes were made.

The images or other third party material in this chapter are included in the chapter's Creative Commons license, unless indicated otherwise in a credit line to the material. If material is not included in the chapter's Creative Commons license and your intended use is not permitted by statutory regulation or exceeds the permitted use, you will need to obtain permission directly from the copyright holder.

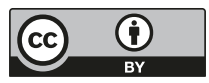

